\title{
Geological Assessment of the Khor Kharfot Sediments, Western Dhofar Region, Sultanate of Oman
}

\author{
Iftikhar A. Abbasi
}

\author{
Department of Earth Sciences, College of Science, Sultan Qaboos University, P.O. Box: \\ 36, PC 123, Al-Khoud, Muscat, Sultanate of Oman. *Email: iftikhar@squ.edu.om.
}

\begin{abstract}
Khor Kharfot is part of a coastal estuarine wetland system located in the western part of the Dhofar Governorate preserving a pristine ecosystem supporting a distinct vegetation and animal habitat. A sand barrier along the khor (local term for wetlands) mouth controls the mixing of fresh and marine water in the enclosed lagoon. In order to understand the geological controls on the khor formation, a geological map of the khor barrier and inlet area is prepared. The khor is bounded by Cretaceous and Tertiary carbonate rock sequences which are cut by a number of faults. The khor mouth and barrier are comprised of late Holocene deposits divided into seven units including i) beach sand, ii) beach sand mixed with wadi gravels, iii) scree and coastal dunes, iv) lagoon, v) soil and boulders, vi) wadi gravels, and vii) talus. The khor developed as an open estuary which changed to a barrier dominated lagoon due to falling fresh water supplies as a consequence of dwindling Khareef rains. The lagoon water is brackish due to the mixing of fresh and marine water and supports a distinct flora and fauna.
\end{abstract}

Keywords: Khor Kharfot; Holocene; Beach; Dhofar; Oman.
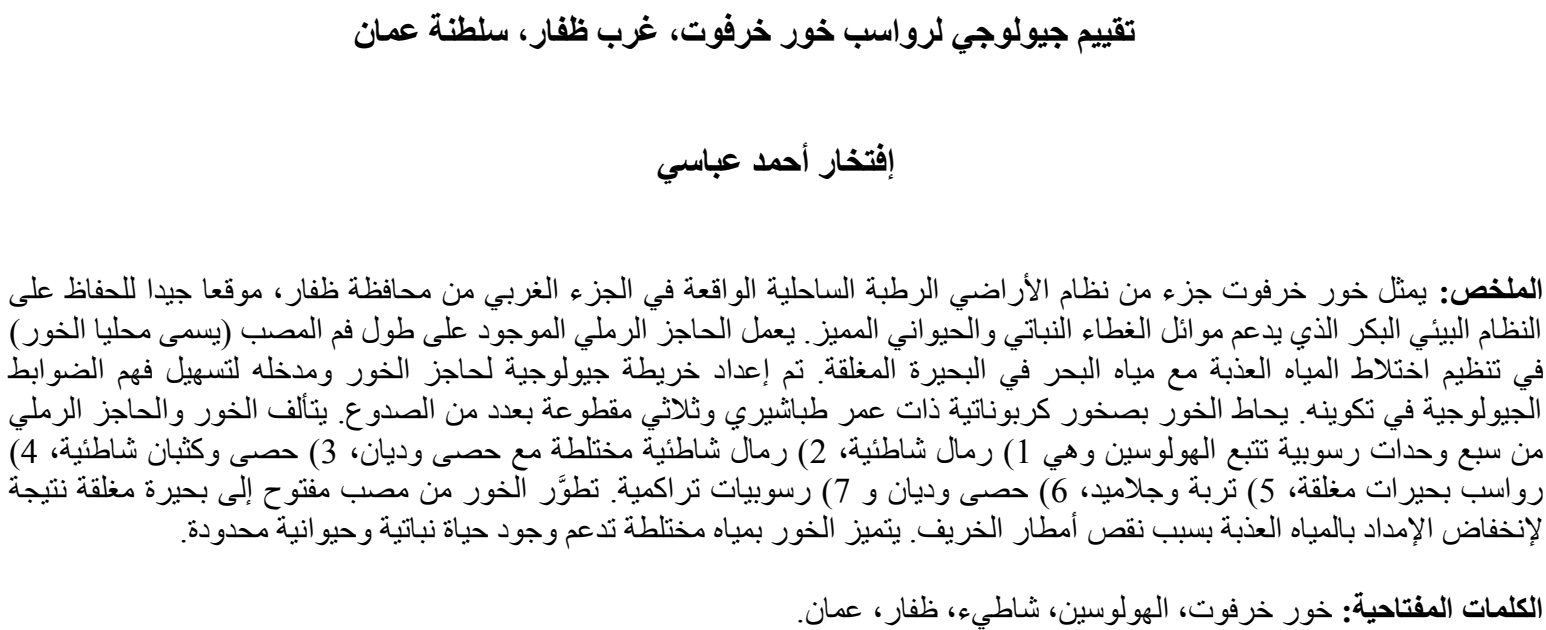

\section{Introduction}

$\mathbf{K}$ hor Kharfot is located in the western Dhofar region about $100 \mathrm{~km}$ west of Salalah city between towns of Rakhyut and Dhalqut (Figure 1), at 16 43 $51^{\prime \prime} \mathrm{N} \& 53^{\circ} 20^{\prime} \mathrm{E}$ along the Arabian Sea coast. Khor Kharfot is part of a narrow coastal plain trending ENE-WSW in front of Jabal Qamar (Figures 2-3), a mountain belt in western Dhofar made up of Cretaceous and Tertiary carbonate rocks [1]. Most of Jabal Qamar is dry and barren except the seaward slopes which are green during summer months as they receive a good amount of Khareef rainfall (Indian monsoon) supporting thick soil cover and vegetation. The seaward $(\sim 5 \mathrm{~km})$ part of the mountain is in the form of high cliffs and escarpments running along the entire length of the coast, and acting as a barrier to the summer monsoon. A number of wadis drain through the Qamar Mountains; these are characterized by ephemeral flow during the Khareef season and usually are dry during the rest of the year. The wadi mouths in coastal areas are in barrier-dominated estuaries or lagoons locally known as khor/khawr. The khors/khawrs are part of the wetlands without mangroves along the coastline, protected from the sea by sand barriers and separated from inland by the mountain escarpments [2-5]. These khors developed during the last approximately three hundred years due to 


\section{GEOLOGICAL ASSESSMENT OF THE KHOR KHARFOT SEDIMENTS}

climatic changes associated with reduced rainfall during the Khareef season [5]. The khors were connected to open sea due to an abundant water supply from the mountains during intense Khareef prior to that time [5]. Most khors in western Dhofar, such as Dhalqut and Rakhyut, are now inhabited and their ecosystems are disturbed by civic activities. Khor Kharfot defines a pristine ecosystem due to limited human activity, as no road or established track crosses through it. The most convenient means to access the khor is from the sea by boat.

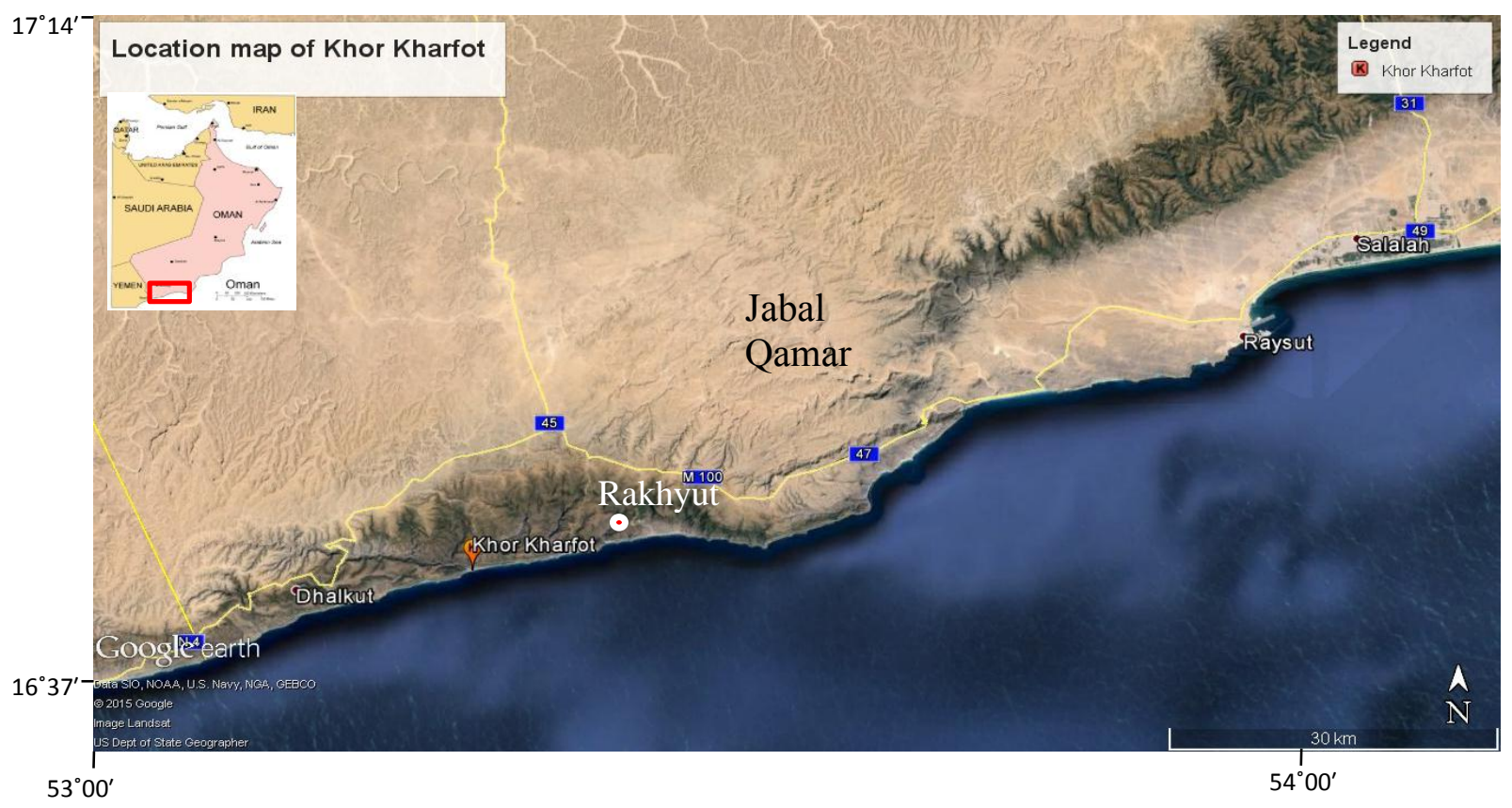

Figure 1. Location map of Khor Kharfot on Google image (Google Professional). Rectangle in inset map shows location of western Dhofar

Most published material relating to the geology of Dhofar deals with the Cretaceous and Tertiary marine deposits [1, 6-9]. Little work has been published on the Quaternary deposits of the region, which make up a large part of the area. Hoorn and Cremaschi [5] is the only work available on the geology of Dhofar khors, including Khor Al-Balid and Khor Rawri near Salalah. The present study is the first of its kind to map the Holocene deposits of Khor Kharfot in the Jabal Qamar area. The khor was mapped with the help of a topographic base map and Google images. The Khor Kharfot is joined upstream by Wadi Sayq and Wadi Kharfot (Figure 2). Both wadis are steep and short, and their beds are littered with large boulders.

\section{Geological Setting}

Jabal Qamar in the western Dhofar region contains thick Cretaceous and Tertiary carbonate rocks partially covered with Quaternary alluvial deposits. The coastal plain along the mountain front is a vast linear belt characterized by Pleistocene-Holocene (Quaternary) sediments deposited along the sea-front. The drainage from the Qamar Mountain passes into the Arabian Sea by a number of wadis and khors, such as Wadi Sayq and Wadi Kharfot (Figure 2). Khor Kharfot is bounded by the Cretaceous and Tertiary carbonate rock sequences which are cut by a number of faults (Figure 3). A major normal fault runs parallel to the left bank of the khor, cutting both the Cretaceous and Tertiary rocks. A number of relatively small scale normal faults also cut through the Tertiary rock sequence. High cliffs and escarpments associated with faulting have resulted in zones of scree and talus, especially along the wadi mouth. The Cretaceous and Tertiary rocks are thick and extend throughout the Qamar Mountains [7]. The rocks are gently dipping (NE) throughout most of the mountain range, defining a vast plateau on top of Jabal Qamar, but forming large escarpments along the coast defined by thick Tertiary Umm Er Radhuma and younger formations. The lower contact of the Umm Er Radhuma Formation with the underlying Cretaceous formations is marked by an unconformity (Figure 4) [1]. The Tertiary sequence is overlain by Quaternary deposits of conglomerate and sandstone derived mainly from the Tertiary limestone and chert lithologies (Aybut \& Gahit members of Umm Er Raduma Formation) during late stage uplift and tectonic deformation (epirogenic movement causing rifting and opening of the Gulf of Aden). A brief description of the Cretaceous and Tertiary units exposed around Khor Kharfot is given below: 
IFTIKHAR A. ABBASI

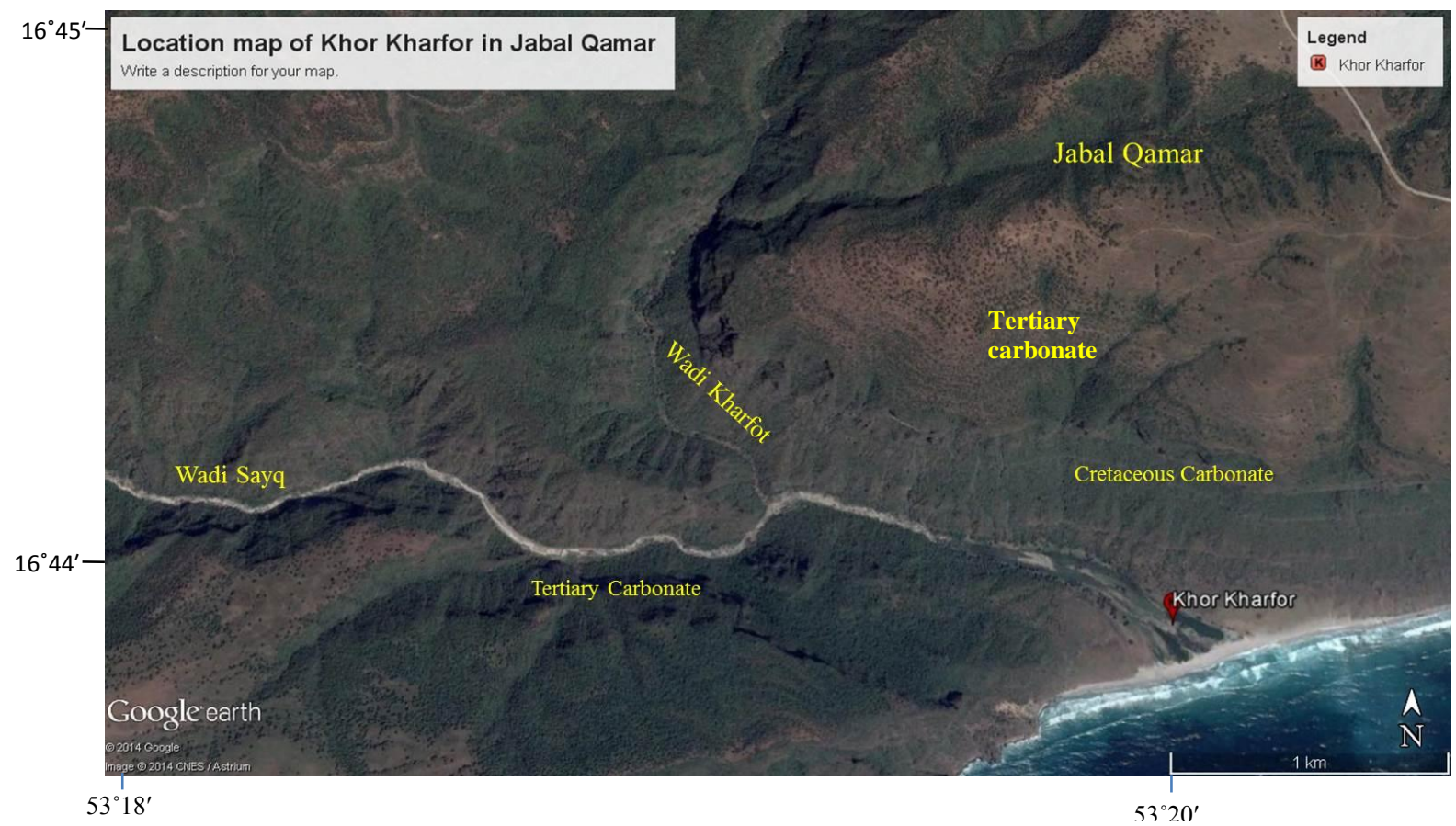

Figure 2. Google image (Google Professional) of Khor Kharfot, wadi Sayq and wadi Kharfot in the Qamar mountains.

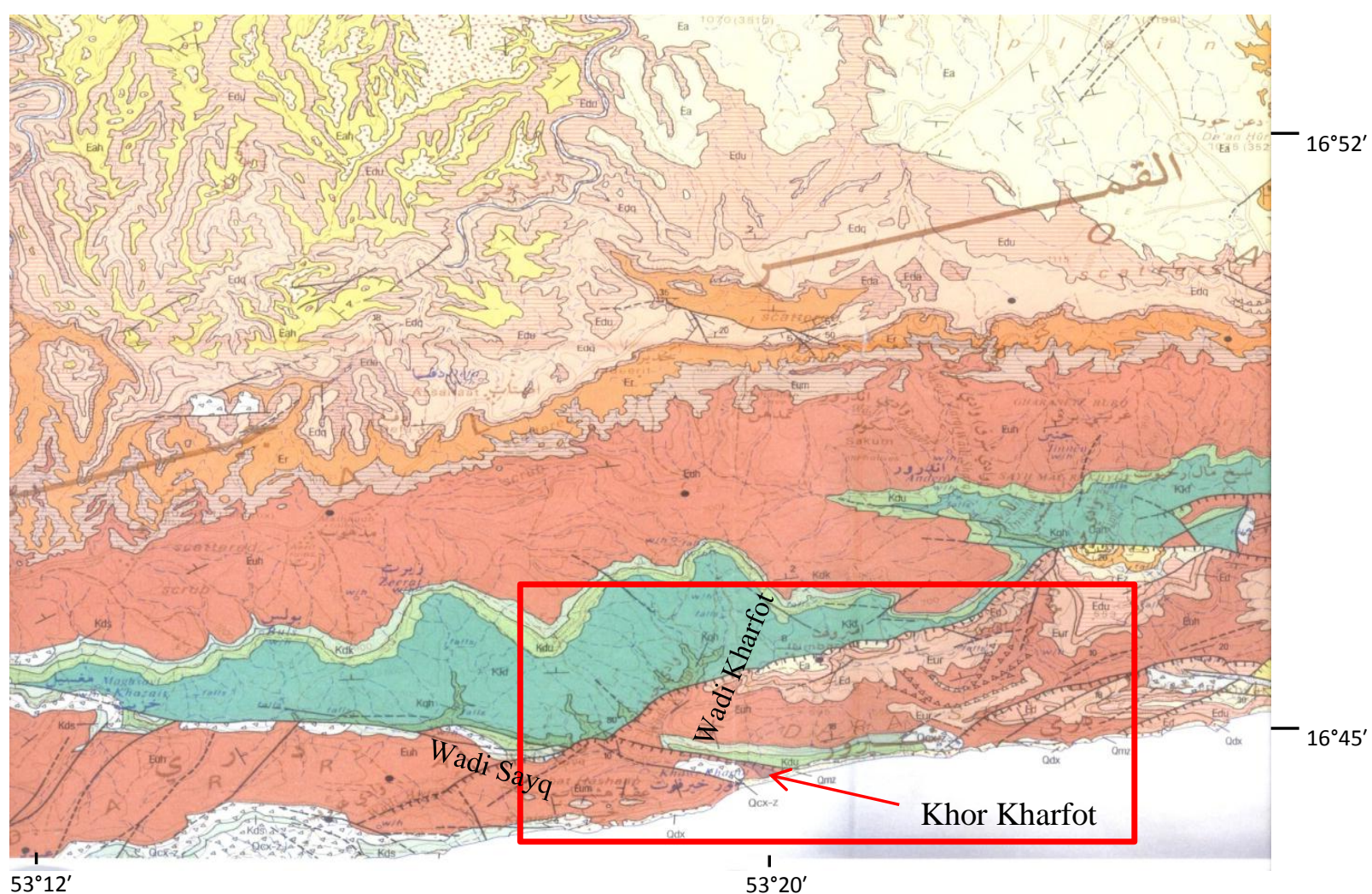

Figure 3. Geological map of Jabal Qamar. Khor Kharfot in inset. Kdu \& Kdk (green \& light green respectively) are Cretaceous rock sequence whereas the rest of the rocks are Tertiary in age. A number of normal faults are shown with solid lines [1].

Cretaceous Rocks: The Cretaceous rocks of the Qamar Group (Kharfot and Dhalqut formations) constitute major part of Jabal Qamar (Figure 4). Along the left (north) bank of Khor Kharfot the Dhalqut Formation is exposed in the lower part of the escarpment (Figure 3). Two members of the Dhalqut Formation identified in the area are the 
Umbaraaf (Kdu) (lower Dhalqut) and Khadrafi (Kdk) (middle Dhalqut) members [1]. The Umbaraaf Member $(\mathrm{Kdu})$ consists of grey marl making a relatively flat part of the outcrops which supports abundant vegetation. The marl sequence is overlain by thick bedded light grey biomicritic limestone containing rudists, orbitlinids, echinoids and radiiolitids [10]. The age of the member is assigned as early to middle Cenomanian [1].

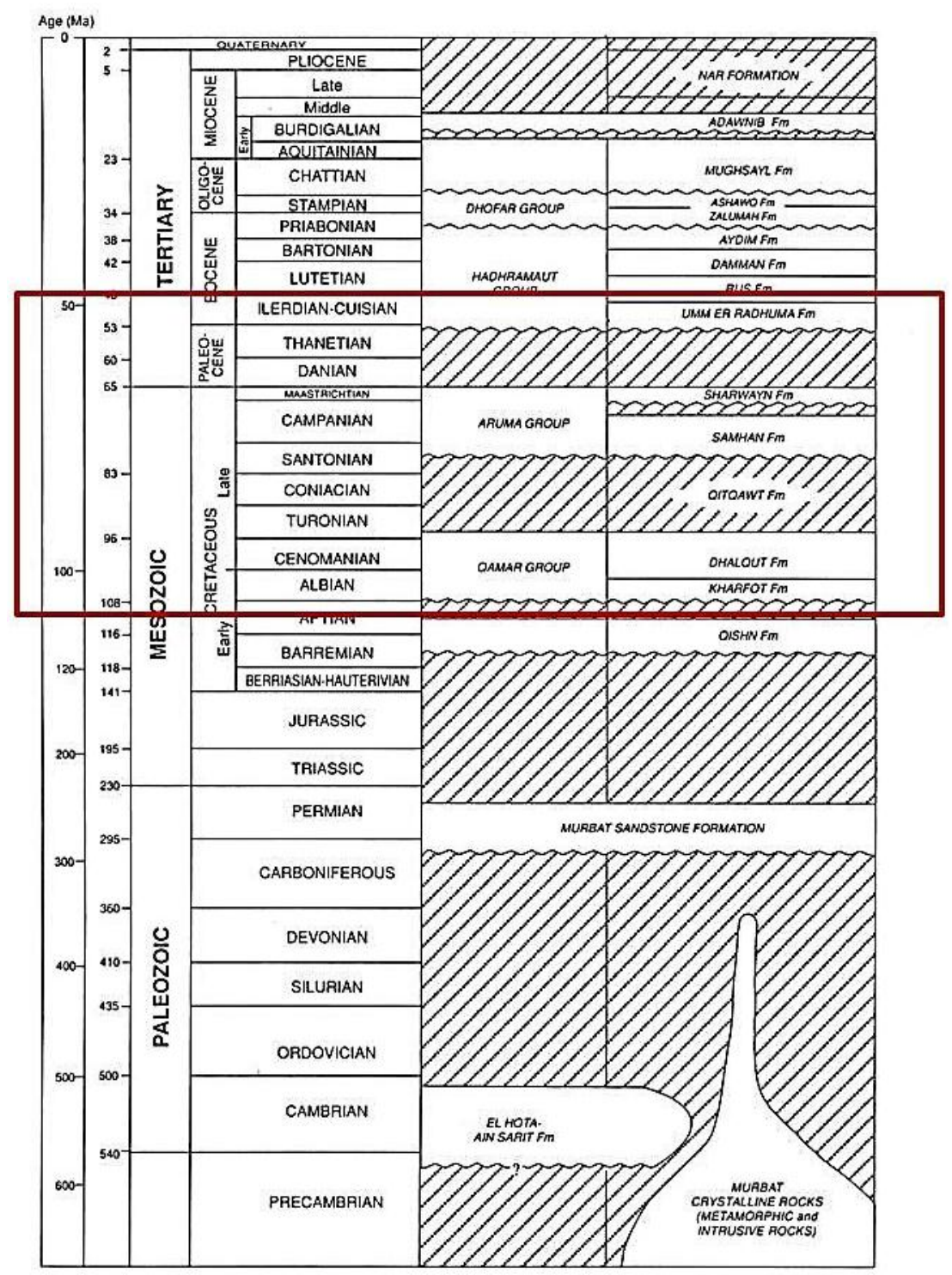

Figure 4. Stratigraphic column of Jabal Qamar around Khor Kharfot. The Cretaceous and Tertiary sequences with an unconformable contact are shown in inset, after [1].

The Khadrafi Member (Kdk) constitutes most of the left (north) flank of the khor and Wadi Sayq, and is comprised of an interbedded sequence of calcareous clays (marl) and fossiliferous, thick bedded limestone. A number of ferruginous hardgrounds are present at various levels in this member and are defined by high fossil concentration, burrowing, and localized iron leaching and concretions (Figures 5. a,b,c). The fauna includes foraminifera (mainly Orbitolinids \& Praealveolinids), echinoids, oysters, algae, nautiloids, rudists, gastropods and brachiopods. The age of the member is assigned as middle to late Cenomanian [1]. 

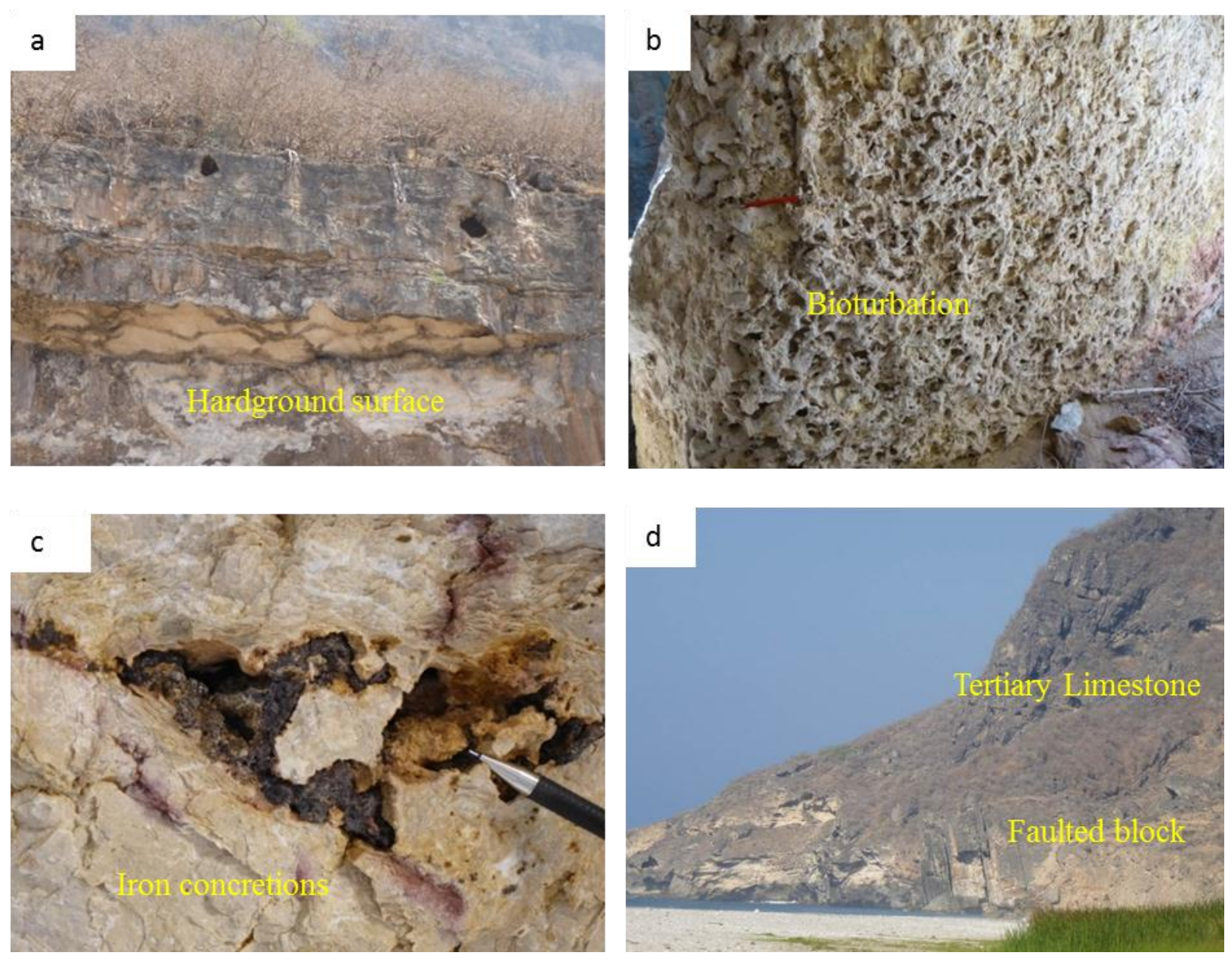

Figure 5. Field photographs of Khor Kharfot; a) Cretaceous limestone with many hardground surfaces, b) extensively bioturbated surfaces in Cretaceous limestone, c) localized iron concretions along hardgrounds in Cretaceous limestone, d) Tertiary limestone with fault blocks along the coast on the right bank of the khor front.

Tertiary Rocks: The Tertiary rock sequence is very thick (>2000 m) and spread over most of the Dhofar region including the Qamar Mountains. It is comprised of Eocene and younger carbonate rocks unconformably overlying the Cretaceous sequence (Figures 3, 4 \& 5d). The Tertiary carbonate rocks belong to the Hadhramaut Group comprising Umm Er Radhuma, Rus, Dammam and Aydim formations [1]. Khor Kharfot and the area around it consist of Atayr and Husk members (Euh in Figure 3) of the Umm Er Radhuma Formation. The Tertiary rocks outcroping along the right (south) flank of the khor and escarpment belong to Atayr and Hasik members (Figure 3). The Atayr and Hasik members consist of greyish marl, recrystalized and partially dolomitized limestone. The Hasik Member in its upper part is composed of hard and compact yellowish to pink recrystalized nodular limestone. Locally, the limestone contains levels of chert and siliceous zones. The uppermost $20 \mathrm{~m}$ of the member contains characteristically large silica concretions which are about one meter in diameter. The formation contains abundant fossils, such as, dasycladacean algae, Nummulites, Alveolina, Discocyclina and Orbitolites. Based on the fossil record both members are assigned to an Early Eocene age.

Quaternary Deposits: The Quaternary age deposits are widespread in and around the Qamar Mountains, especially along the wadis, khors and coastal plain (Figures $6 \&$ 7) [5]. These can be broadly divided into alluvial and littoral deposits. The alluvial deposits are comprised of pebbles to boulder size clasts of limestone along wadi floors and banks. Older terraces are reported from other wadis, but none occurs in Wadi Sayq, Wadi Kharfot and Khor Kharfot [1]. The wadi floor of both wadis, Sayq and Kharfot, are littered with large boulders derived from the wadi escarpment (Figure 8. a, b, c). The colluvial deposits, such as talus, are accumulated everywhere along the foot of escarpments and wadi floors. In Khor Kharfot, talus deposits are dominant on both sides of the khor, especially along the major landslides in the Tertiary limestone escarpment.

Littoral deposits in the form of beach sand and indurated sand dunes are found along and adjacent to the coast. The khor barrier possibly developed during the past three thousand years due to a dwindling fresh water supply from the mountains as a consequence of low Khareef intensity. The khor barrier has been breached many times during past years, this being associated with occasional intense rainfall. In Khor Kharfot, the beach deposits are widely distributed along the khor mouth, while indurated sand dunes are preserved a few kilometers to the 
west along the coast between Khor Kharfot and Dhalqut. The indurated sand dunes are preserved as hundreds of meters long and tens of meters thick sandstone bodies along the coast, and are comprised of large scale, high angle cross-stratification (Figure 8d). The dunes are probably of Pleistocene age and are well cemented with carbonate cement.

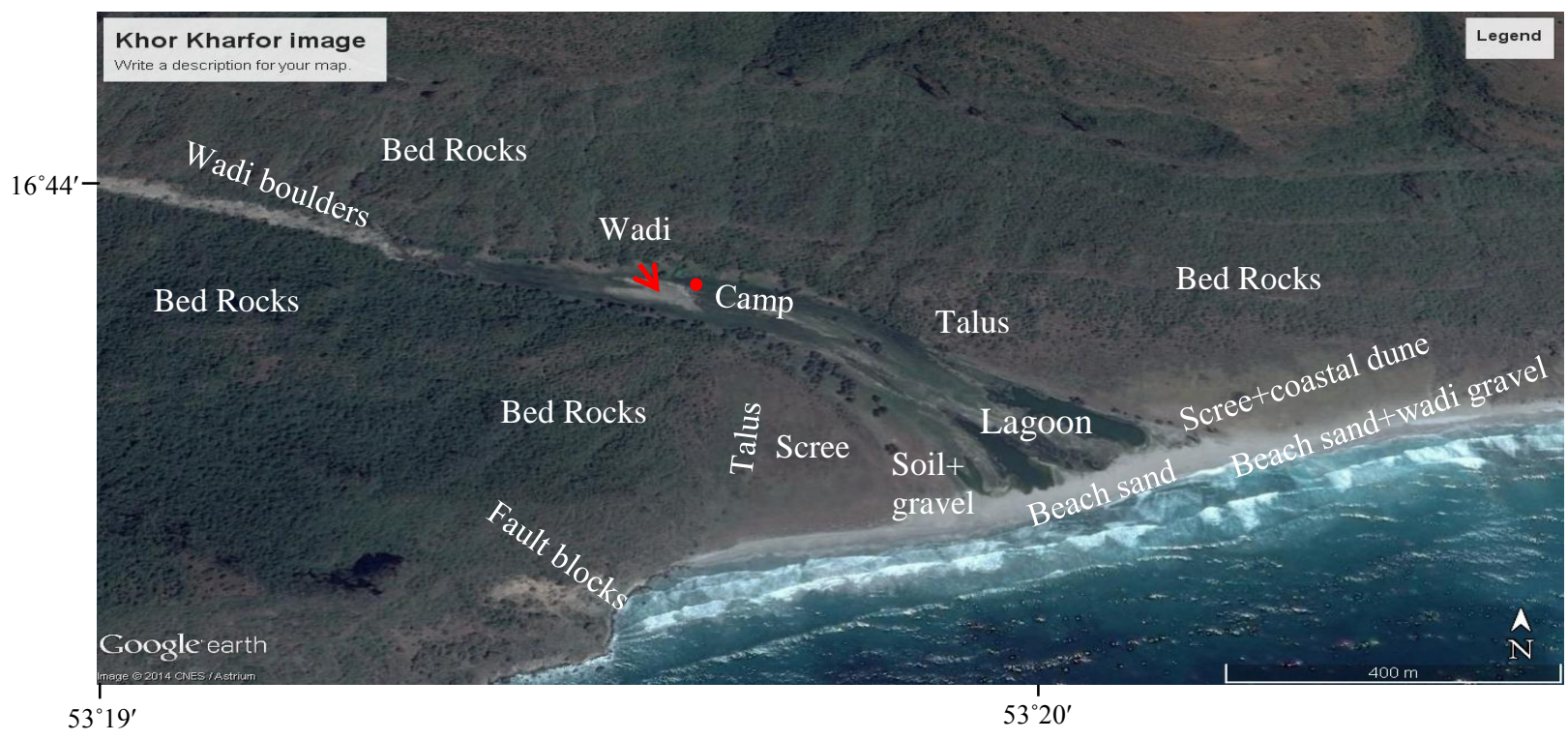

Figure 6. Google image (Google Professional) of Khor Kharfot showing areal distribution of the major lithological units.

\section{Geology of Khor Kharfot}

In order to study the Holocene geology of Khor Kharfot, a geological map is prepared by describing the various lithologic units present in the khor mouth (Figure 7). Khor Kharfot from the khor mouth to inside the wadi consists of six units named as beach sand, beach sand mixed with wadi gravels, scree and coastal dunes, soil and gravels, wadi gravels, and talus (Figures $6 \& 7$ ). The beach sand and beach sand mixed with wadi gravel units make a barrier behind which a permanent lagoon with weed and trees is present (Figures $6 \& 7$ ). Overall these units are about $4 \mathrm{~m}$ high, high enough to hide the khor from the sea-side. A description of each unit is given below:

Beach Sand: Clean, white colour beach sand extends all along the coastline of the khor-mouth in a $50 \mathrm{~m}$ wide zone (Figures $7 \& 9$ a,b). It is composed of sand size limestone particles and shell debris. Ripple marks, organism (crab) tracks and mounds are common (Figure 9b). The sand is fine to medium-grained, well sorted with abundant fine sand-sized skeletal debris probably derived from bivalves and gastropods, and spines of Alcyonaria (octahedral corals). Foraminifera and ostracod shell fragments, though present, are few in number.

Beach sand mixed with gravel: This unit is comprised of white beach sand mixed with rounded limestone gravels, making a resistant barrier for waves (Figure 9c). The unit is over one meter thick and 20-25 m wide extending on both sides of the khor mouth above the beach sand. The wadi pebbles are well rounded, and medium to poorly sorted with all clast sizes. White wadi gravels are extensive on both sides of the khor but are less common in front of the lagoon.

Coastal sand dunes mixed with scree: Fine sand mixed with gravels and cobbles forms a zone about $100 \mathrm{~m}$ wide on the face of the khor but thins out inside the khor. Some of the coastal sand is indurated with pebble to boulder sized carbonate clasts (Figure 9d). Sediments of this unit are spread over a large part of the khor mouth. Most of the flat area over which old farming fields and ruins were established is located in this unit. The scree consists of limestone clasts derived from bedrocks and is comprised of all possible clast sizes, ranging from pebble to boulder sizes. 
IFTIKHAR A. ABBASI
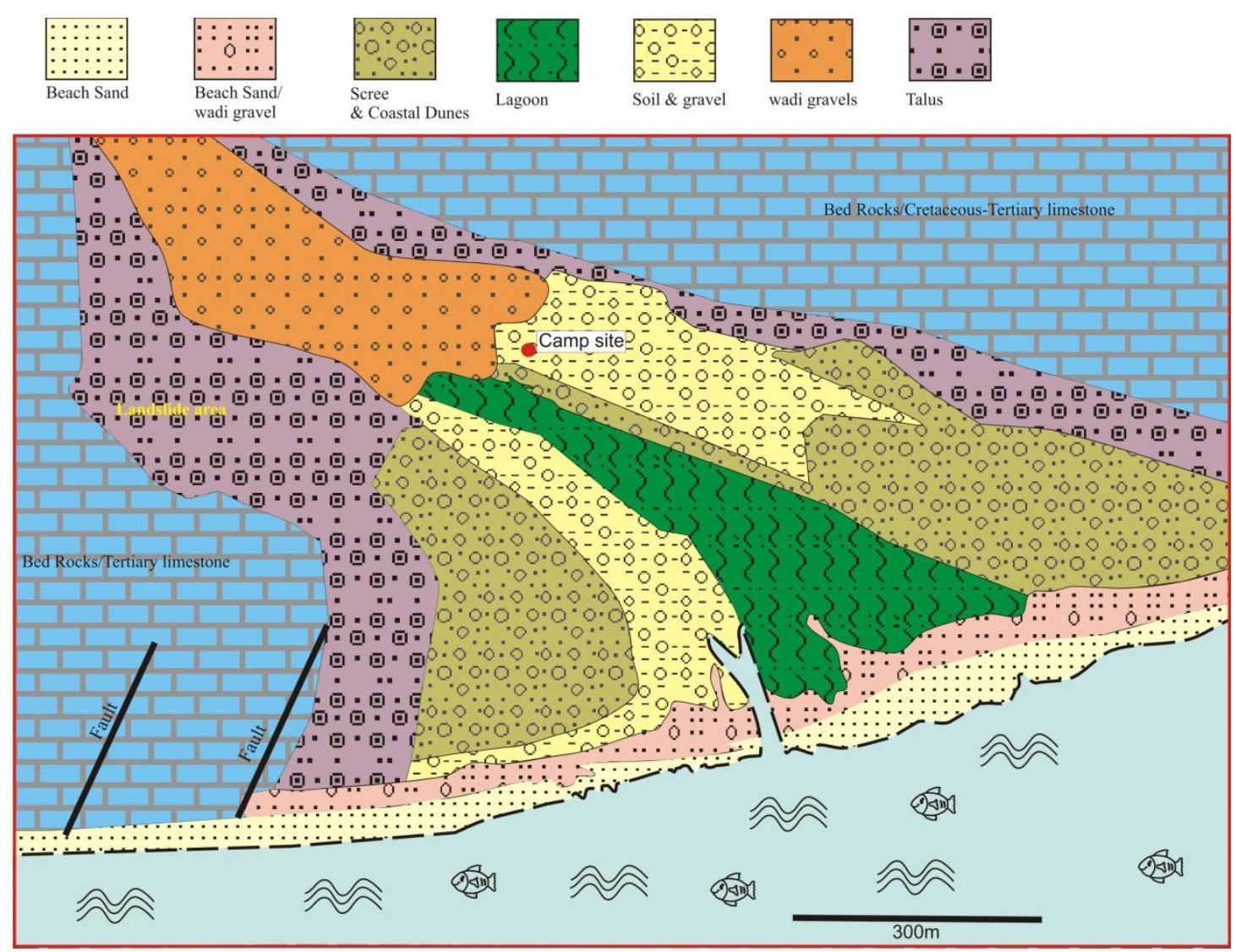

Figure 7. Map sketching the lateral distribution of the various sedimentary units exposed in Khor Kharfot
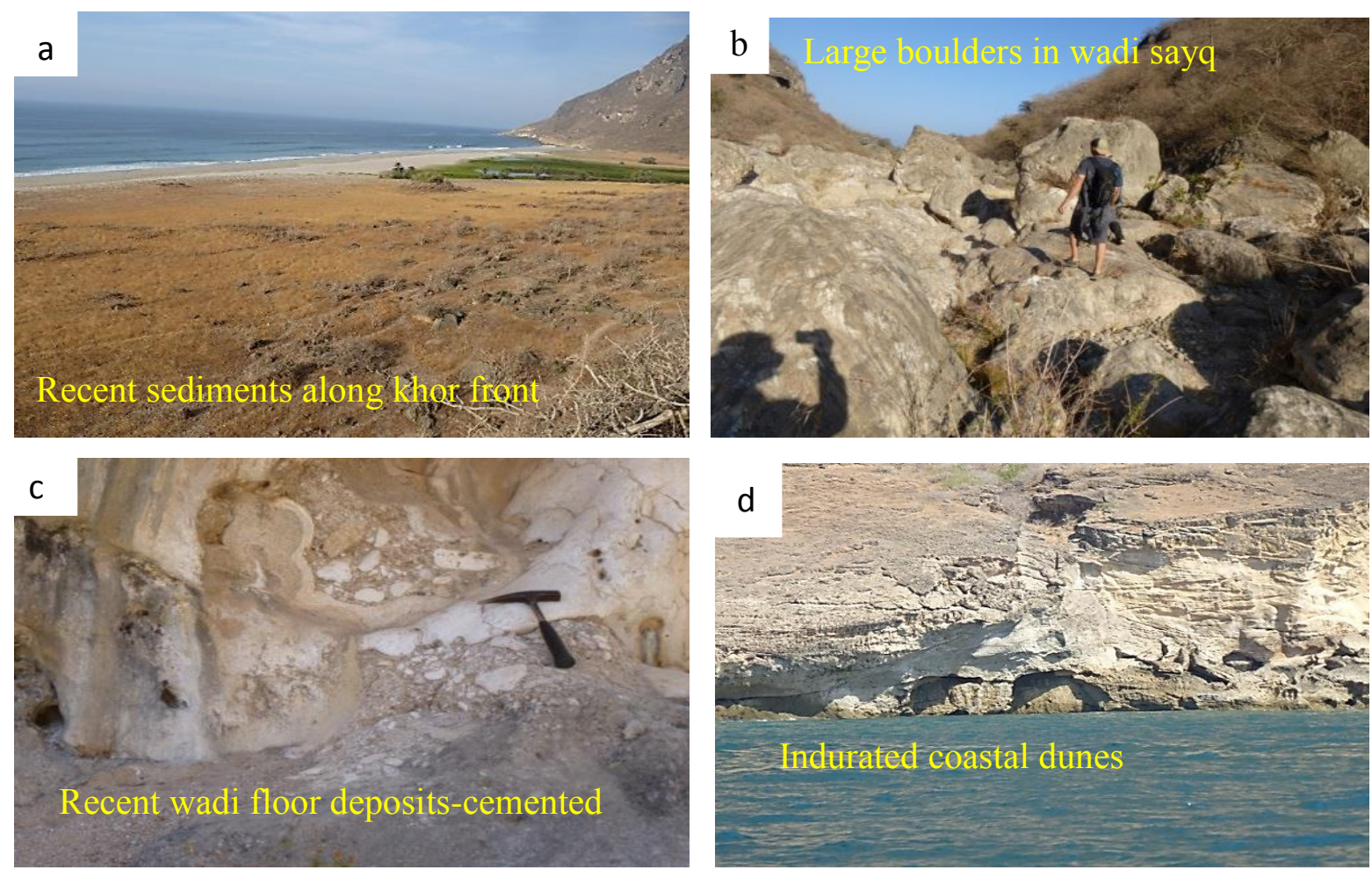

Figure 8. a) Recent sediments along the khor front, b) large boulders of limestone on the wadi floor, c) Indurated wadi boulders and pebbles cemented by surface process, d) Indurated coastal sand dunes deposited along the coastal area. 


\section{GEOLOGICAL ASSESSMENT OF THE KHOR KHARFOT SEDIMENTS}

Lagoon: A large brackish water permanent lagoon covers the major part of the khor (Figures 6, 7 \& 9a). The lagoon is separated from the sea by a beach barrier ridge made of beach sand and beach sand mixed with wadi gravel units. The barrier is unconsolidated and is breached during events of wadi flooding. The lagoon is almost at sea level, just over one meter below the sand barrier formed during monsoon storms and which closes the khor mouth completely. The lagoon has an approximately one meter thick organic rich mud cover, which supports weeds and bushes along with a number of bird species. The lagoon is fed by sea-water through narrow inlets during high tides, by water draining from the spring near the camp-site, and by the Khareef.

Soil and gravels: On both sides of the lagoon, there are localized areas of very fine silt and clay supporting grass and weeds, and covered with wadi gravels and boulders (Figure 6, $7 \& 9 \mathrm{e}$ ). This unit is inundated during high wadi flow in the Khareef season and at very high tides.

Wadi gravels: Gravels of all sizes ranging from large boulders to pebbles which cover the wadi beds of both wadis Kharfot and Sayq are also present in the khor area, particularly towards its upper part (Figure 6, 7 \& 9f). The older wadi gravels are indurated and could be part of an older escarpment. The wadi gravels are limestone clasts derived from the Cretaceous and Tertiary bed rocks. The wadi floor is littered with very large, many meters in diameter boulders on top of indurated gravels.

Talus: Both sides of the khor at the base of the escarpment are littered with talus which is comprised of soil and large boulders of limestone. It is particularly common in areas associated with large landslides (Figures 5d, 6, 7). Such a landslide is prominent on the right (south) bank of the khor. The soil cover (which is of considerable thickness along the slope of the escarpment) slides down during the rainy season, usually along the fault planes which are common in the area.

Economic Minerals: No economic minerals are reported from the khor area, and none were discovered during this study. A few localized iron mineralizations and nodules are found along hardgrounds in the Cretaceous limestone but are not of any economic significance. Chert/flint which was commonly used in paleolithic times for tool making is common in the Tertiary limestones.

\section{Khor Formation}

The Dhofar mountain belt, including the Qamar mountains, was uplifted during Oligocene-Miocene rifting and the opening of the Red Sea/Gulf of Aden [11, 12]. The tectonic uplift was associated with the development of a number of faults and escarpments along the Arabian Sea. The fault system provided convenient weak lineaments for the drainage system in the form of large wadis, such as Wadi Sayq and Wadi Kharfot, draining into the sea. A number of khors, such as Khor Kharfot, developed at the wadi mouths due to the interaction of wadi and sea water under varied climatic influences during the Holocene time.

The Middle to Late Holocene was a period of higher intensity monsoon in Oman than the present time, as interpreted by the presence of Rhizophora in qurm deposits of north Oman [13] and an oxygen isotope study of stalagmite in cave deposits [14]. Hoorn and Cremaschi [5] also suggested wetter conditions in Dhofar region on the basis of microfauna, though did not find any Rhizophora pollen in khor sediments of the area. These environmental changes are linked both to climate and sea-level variations. The khor development during the Recent time is attributed to reduced rainfall, especially during the Khareef season, which led to the aggradation of barrier and coastal sand dune accumulation and the development of coastal wetlands in the Dhofar region.

The wetlands in western Dhofar, such as Khor Kharfot, most likely formed as small estuaries which were later protected from the sea by coastal sand barriers. These sand barriers are comprised of beach sand and coastal sand dunes and wadi gravels protecting a lagoon which is almost at sea-level. The lagoon receives a good amount of fresh water during Khareef rains, besides water from nearby spring and subsurface groundwater recharge. The groundwater recharge is subsiding due to pumping stations in Wadi Sayq, which is the main tributary of the khor. The sea water also drains into the lagoon through tidal inlets during high tide, and also possibly enters due to seawater seepage through the barrier sand. The barrier is often breached during heavy rainfall in the mountain region leading to flooding in the wadis and khor. The lagoon water becomes highly brackish during these events. Conspicuously absent in the khor are beach-rocks, as no evidence of beach rocks and terrace development is noticed in the Khor Kharfot. 

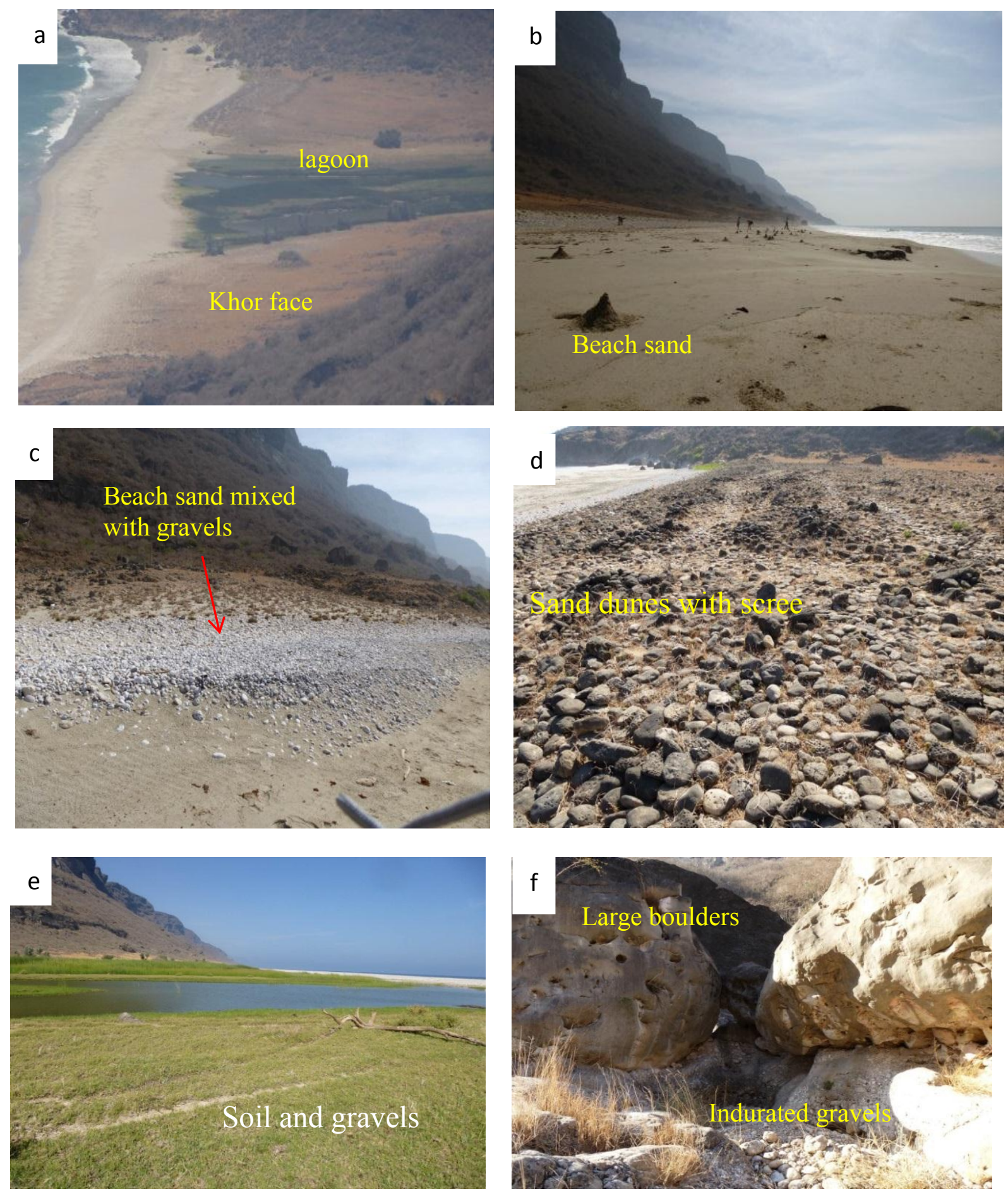

Figure 9. a) Khor Kharfot lagoon and associated sediments along the khor mouth, b) closer view of beach sand unit with crab mounds, c) beach sand mixed with wadi gravel unit overlying the beach sand unit, d) sand dunes blown from beach sand covered with scree, e) soil mixed with gravel unit on both sides of lagoon, f) wadi gravel and boulder unit. The lower gravel beds are cemented by carbonate cement.

\section{Conclusion}

1. Cretaceous and Tertiary rocks constitute the Khor Kharfot banks, with a well pronounced escarpment related to faulting in the area.

2. Khor Kharfot is characterized by a sand barrier that protects a lagoon supporting abundant vegetation, birds and other animal life.

3. The Khor Kharfot barrier developed during the Recent time due to a decreasing Khareef, as compared to that of Middle and Late Holocene time. The barrier is being regularly breached during high precipitation events in the Khareef season, and subsequently rebuilt. 


\section{GEOLOGICAL ASSESSMENT OF THE KHOR KHARFOT SEDIMENTS}

\section{Acknowledgement}

Warren Aston, Chairman of the Khor Kharfot Foundation organized trips and facilitated work in the area. Neil Prendergast and Chad Aston were very helpful during field visits and also in providing logistic facilities. Drs. Michele Esposti and Carl Phillips are thanked for their discussion in the field. Scot Proctor, Mariah Proctor, Maurine Proctor, Dr. Mark Hamilton, Dr. Rick Hauck and Caleb Barnes are gratefully acknowledged for their company during my stay in Khor Kharfot. Daniel Moraetis is thanked for reviewing the manuscript. Comments and suggestions from two anonymous reviewers substantially improved the manuscript. Dr. Mohammed AlWosabi, Visiting consultant in the Earth Science Department helped in Arabic translation.

\section{References}

1. Platel, J-P. Explanatory Notes to the Geological Map of Hawf, Sheet NE 39-16B, Scale:1:100,000. Muscat, Oman. Directorate General of Minerals, Oman Ministry of Petroleum and Minerals, 1987, 48pp.

2. Clarke, N.V., Al-Ma'ashani, M.M, Saleem, M. and Dyras, I. Physical parameters of khawrs. Khawrs and springs of the Dhofar Governorate, Survey and monitoring studies. Planning committee for development and environment in the Governorate of Dhofar, Sultanate of Oman. 1993,2.

3. Abdel-Megid Abdel-Salam, H. Ecology and fauna of sandbars of some khawrs (coastal lagoons) of Dhofar. Khawrs and Springs of the Dhofar Governorate, Survey and monitoring studies. Planning committee for development and environment in the Governorate of Dhofar, Sultanate of Oman, 1993, 2.

4. Victor, R., Victor, J.R. and Clarke, N.V. Physical and chemical environment of Khawr Mugsayl, a coastal lagoon in southern Oman. Journal of Arid Environments, 1997, 36, 1-14.

5. Hoorn, C. and Cremaschi, M. Late Holocene paleoenvironmental history of Khawr Rawri and Khawr Al Balid (Dhofar, Sultanate of Oman). Palaeo. Palaeo. Palaeo. 2004, 213, 1-36.

6. Qidwai, H.Y. Geological Map of Uyun (1:100 000)-Explanatory Notes. Ministry of Petroleum and Minerals, Directorate General of Minerals, Oman. 1988.

7. Salad Hersi, O., Al-Harthy, A., Abbasi, I.A., Al-Sayig, A. and Al-Lazki, A. Hydrocarbon potential of the Jeza-Qamar Forntier Basin, Dhofar, Southern Oman. In: Detective Stories Behind Prospect Generation: Challenges and the Way Forward. European Association of Geologists and Engineers (EAGE) Workshop, April 2009, Muscat. Extended Abstract: 2009, 29-33.

8. Hersi O.S., Abbasi, I.A., Al-Harthy, A., Cherchi, A. and Schroeder, R. Stratigraphic evolution and depositional system of lower Cretaceous Qishn formation, Dhofar, Oman. In Tectonic Evolution of the Oman Mountains (eds Rollinson, H.R., Searle, M.P., Abbasi, I.A., Al-Lazki, A. \& Al Kindi, M.H) Geological Society London Special Publication, London, 2014, 392, 303-323.

9. Salad Hersi, O. Lithologic and diagenetic attributes of the Sharwayn (Maastrichtian) and Umm Er Radhuma (late Paleocene-Eocene) formations and their significance to the K-T unconformity, Jabal Samhan area, Dhofar, Sultanate of Oman. Arabian Journal of Geosciences, 2011, 4, 147-160.

10. Salad Hersi, O., Abbasi, I.A. \& Al-Harthy, A. R. Cretaceous Lithostratigraphy of Eastern Jeza-Qamar Basin and its Hydrocarbon Potential, Dhofar, Oman. Canadian Society of Petroleum Geology Convention, Calgary. 2013, 1-5.

11. Ziegler, M.A. Late Permian to Holocene paleofacies evolution of the Arabian Plate and its hydrocarbon occurrences. GeoArabia, 2001, 6(3), 445-504.

12. Bosworth, W., Huchon P. and McClay K. The Red Sea and Gulf of Aden Basins. Journal of African Earth Sciences, 2005, 43, 334-378.

13. Le'zine, A.M., Salie`ge, J.F., Mathieu, R., Tagliatela, T.L., Mery, S., Charpentier, V. and Cleuziou, S. Mangroves of Oman during the Late Holocene: Climatic implications and impact on human settlements. Vegetation History and Archaeobotany, 2002, 11, 221-232.

14. Fleitmann, D., Burns, S.J., Mudelsee, M., Neff, U., Kramers, J., Mangini, A. and Matter, A. Holocene forcing of the Indian monsoon recorded in a Stalagmite from Southern Oman. Science, 2003, 300, 1737-1739.

Received 26 March 2015

Accepted 7 December 2015 